Research.

\title{
Correlation between the student's perception about professional public accountant and the intention to pursue the career in auditing at the students of department of accounting STIE Binaniaga
}

\author{
Rizki Ahmad Fauzi \\ Department of Accounting, Economic College of Binaniaga, Bogor, Indonesia \\ hafari3327@gmail.com (R. A. Fauzi)
}

Received: February 18, 2019; Accepted: April 28, 2019; Published: June 30, 2019.

To cite this article: Fauzi, Rizki Ahmad. (2019). Correlation between the student's perception about professional public accountant and the intention to pursue the career in auditing at the students of department of accounting STIE Binaniaga. The Accounting Journal of BINANIAGA. 4 (1): 49-56. doi:

\begin{abstract}
This research aims to figure out the students' perception about public accountant and their interest to be an auditor. Population of this research are the active students in the department of accounting at STIE Binaniaga year of 2016 (Semester 5) Sampling technique has applied Stratified Random Sampling and the quantity of the samples are 30 students after getting thru some sampling selection. Dependent variable is the students' intention to work in auditing. And independent variabe is the students' perception about professional accountant. The result of this research has indicated a significant correlation is occured between the students' perception about public accountant and the students' interest to pursue working in auditing.
\end{abstract}

Keywords: Public Accountant, interest, students perception.

\section{Introduction}

Some cases of the companies which are having problems about financing and government offices which are facing financial scandal or money laundering have been creating big impact for the students. An impact of such the scandal could directly or indirectly have affected the interest of the students to pursue a career in auditing. That kind of possibility has been questioned by the department of accounting or professional public accountant which is it will happen and will jeopardize professional auditing. Such a big risk has been considered by the students who want to be an auditor. In general, accounting scandals will produce a continuous crisis in the perception of huge society which is called the professional ethics crises. Any kind of professional scandal will make the reputation of related profession negative in the public point of view. However, such a scandal will block the recruitment of new employees for such the profession required (McLeod, 2002 and Greengard, 1996 in Cormunale et.at, 2006). Indonesia has quite small total of public accountant. According to the article on IAI website on 14 March 2013, mentioning that the total of public accountants in Indonesia was only 1,000 persons in 2012 which made Indonesia beyond Malaysia which has had 2.500 public accountants and so other countries.

The above facts has made Indonesian accountancy tragic since there has been negative perception about public accountant especially in auditing as described above. Based on the previous facts describing about the impact of accountancy scandals in 20th century has been an interesting topic to study related to the issue of ethics crises

Rizki Ahmad Fauzi. Correlation between the student's perception about professional public accountant and the intention to pursue the career in auditing at the students of department of accounting STIE Binaniaga 
happened on the students of department of accounting. Nevertheless, this research aims to figure out furthermore about the interest of the students at STIE Binaniaga to pursue a career in auditing. This research aims to measure the correlation between the students' perception about public accountant professional and the students' interest to be an accountant.

\section{Library Review}

\section{Perception}

Sugihartono, et.al (2007:8) described that perception is a brain ability to translate a stimulus or a process to translate the stimulus entering the five human senses. Human perception is related to the different point of view or sensory perception. Someone who has perceived something good or positive or negative will influence his actual action.

Based on some perception definitions above, it is concluded that perception is a personal feed-back to perceive or to evaluate something according to the information received. Perception has created a picture about something that he or she is interested in.

\section{Interest}

W.W.S. Winkel said that an interest is a firm tendency to be interested in a certain subjects and people will be happy doing it (1983:38), but according to Witherington (1985:38) an interest is a person intention on a certain object, someone, something or situation which is related to his/her awareness.

\section{Public Accountant}

A public accountant is an accountant who has got a license issued by the ministry of finance in order to provide a service as public accountant (see below). In Indonesia the regulation about public account is determined on the Regulation of the Republic of Indonesia number 443/KMK.01/2011 regarding the determination of the Indonesian Public Accountant Institution as the Association of Indonesian Public Accountant (IAPI).

The establishment and development of professional public accountant in one country is relying on the development of varied type of companies and legal institutions in that country (Mulyadi, 2002). A company will need the capital / finance to run its business. The capital / finance can be received from internal company (owner) or external company (investor and loan from the creditor) Therefore, a proper financial report is required by both parties refers to the decision making related to the company. The financial report that will be prepared is an information description about the responsibility of the management to manage the finance either from external or internal company (Setiyani, 2005).

\section{Method of The Research}

This research has applied quantitative approach which is correlative study. The variables used in this research are the interest of the students who want to work at the Public Accountant Office and the interest of the students who want to pursue a career in auditing as dependent variable. And independent variable is the perception about professional public accountant. Target population of data collection technique is all the students in the department of accounting at STIE Binaniaga year 2016. Sampling technique has applied Stratified Random Sampling where samples identification is done by dividing the population in two groups which is active students year 2016 .

Rizki Ahmad Fauzi. Correlation between the student's perception about professional public accountant and the intention to pursue the career in auditing at the students of 
1. Requirement Test

a. Normality Test

The availability of Normal distribution data or close to normal one will produce an applicable regression model that can be used in a research (Nugroho, 2005). This research has applied Kolmogorov Smirnov and the data will distribute normal if $\mathrm{Sig}>0.05$.

b. Autocorrelation Test

This test is done to find out whether any correlation between error-term in the data has occurred. In order to find out whether any autocorrelation is happened or not, and the identification of error at every observation is correlated or not, it is identified by the value of Durbin Watson (DW) on the table of summary model (Sulaiman, 2004). Obviously the autocorrelation will never happen if $\mathrm{du}<\mathrm{DW}<$ (4-du).

c. Multicolinearity Test

Multicolinearity detection of this research has applied VIF tolerance refers to the requirements that if Variance Inflation Factor (VIF) $<10$ and tolerance value $(\mathrm{TOL})>0.1$, this model is free from multicolinearity.

d. Heteroscedasticity Test

Heteroscedasticity test used in this research is Glejser test that will regress a residual absolute value (AbsUi) upon other independent variables using regression equation. If the significant value is less than 0.05 , the regression model will have heteroscedasticity issue (Ghozali, 2009).

2. Hypothesis Test

a. Multiple Linear Regression

This research has applied 3 regression models and each model represents one dependent variable. $M 1=a+b 1 B 4+b 2 P r+b 3 S k+\varepsilon M 2=a+b 1 B 4+$ b2 $\operatorname{Pr}+b 3 S k+\varepsilon M 3=a+b 1 B 4+b 2 \operatorname{Pr}+b 3 S k+\varepsilon$

Descriptions: M1: Interest of the students to work in the Government Public Account Office, measured by using 5 scales of Likert for 1 question. M2: Interest of the students to pursue a career in the Public Accountant Office, measured by using 5 scales of Likert for 1 question. M3: Interest of the students to pursue a career in auditing, measured by using 5 scales of Likert for 1 question. B4: Perception of the students about the Public Accountant Office. Pr: Perception of the students about professional Accountant. Sk: Perception of the student about accountancy scandals. Determinant Coefficient Test $\left(R^{2}\right)$ Result of $R^{2}$ value will identify the ability of independent variables explaining dependent variable, but the rest is influenced by the other factors which are excluded from independent variables. If the coefficient value is close to 1 , the ability of independent variables identifying dependent variable will be bigger.

b. Test of Correlation Coefficient ( $r$ )

This research has applied Pearson correlation test, if the value of correlation $(r) \geq 0.5$, it has indicated that there is a strong correlation happened between two variables which their correlation is tested. If Sig.value $<0.05$, it indicates that a correlation has happened between two variables.

c. F test

This test is done by comparing the probability value of $F$ test with significance level $\alpha=5 \%$. If sig.value of $F$ test $<\alpha$ value, it explains that the effect of independent variables simultaneously has happened upon the dependent variable, nevertheless, $\mathrm{H} 1$ is accepted.

d. T test

$T$ test is done by comparing the significance level of $T_{\text {test }}$ result with $\alpha$. When the value of $t$-count $<\alpha$, which is $\alpha$ value $=0.05$, it can be indicated that a

Rizki Ahmad Fauzi. Correlation between the student's perception about professional public accountant and the intention to pursue the career in auditing at the students of department of accounting STIE Binaniaga 
significant correlation has happened between independent variables and dependent variable partially.

\section{Result and Description}

1. Requirement Test

Using Kolmogorov Smirnov test, it has obtained that data of $0.101 ; 0.222$; 0.063 . And the value $(p>0.05)$ indicating that the three dependent variables of this research have distributed normal.

2. Autocorrelation Test.

Based on the test result of Durbin Watson, the three regression models are having the value ot Durbin Watson counted in the area of No Autocorrelation, so that it is concluded that there is not any autocorrelation happened on the three regression models.

3. Multicolinearity Test

The result of the three regression has obtained the Tolerance value of more than 0.1 and VIF value of less than 10, therefore, it can be concluded that the three regression models have not produced any multicolinearity among the independent variables.

4. Heteroscedasticity Test

For regression model $1 \& 2$, there are not any heteroscadicity issues happened, but, regression model 3 is having hetroscedasticity issue. It has indicated that regression model 3 is not efficient and does not have any minimum variance which is it is not in BLUE anymore or Best Linear Unbiased Estimator (Ghozali, 2009), though, it is still enable to be used for the research because all the independent variables which are not getting thru are the main variables of this research.

Result of Hypotheses Analysis using Multiple Linear Regression

1. Determinant Coefficient Test $\left(R^{2}\right)$

$R^{2}$ value of the three regression models is not more than 0.2 , it means that the percentage of dependent variable which can be identified by the independent variable is not more than $20 \%$ and the rest is described by other external variables of the research.

2. Correlation Coefficient Test ( $r$ )

The three regression modesl have a close and weak correlation or the weakest one with the three independent variables of B4, Pr and SK.

3. F test

On the regression models 1 and 2 , the three independent variables simultaneously have correlated with the variables M1 \& M2 which is the interest of the student who want to be a public accountant at the Government Office and the interest of the students who want to pursue a career at the Public Accountant Office, but on the regression model 3 , the three independent variables simultaneously have not correlated with $\mathrm{M} 3$ which is the interest of the students who want to pursue a career in auditing.

4. T test

On the regression model 1 , it is only variable B4 having negative and significant correlation with M1 which is the interest of the students who want to be a

Rizki Ahmad Fauzi. Correlation between the student's perception about professional public accountant and the intention to pursue the career in auditing at the students of 
public accountant at the Government Office. On the regression models 2 and 3 , it is only $\operatorname{Pr}$ variable having negative and significant correlation with $\mathrm{M} 2$ and $\mathrm{M} 3$ which is the interest of the students who want to work at the Public Accountant Office and the interest of the students who want to pursue a career in auditing. Negative value of B4 and Pr has indicated that a reverse comparative correlation has occured between B4 variable and $\operatorname{Pr}$ variable upon the three variables of this research. The description of the students' perception about becoming a public accountant or an auditor at the government office has depicted a negative and significant correlation upon the interest of the related students who want to work in the Public Accountant Office (M1). It has indicated that the more perception of the students about some cases at the government office happened, the less students who want to be a public accountant at the government office and vice versa.

Result of this research is in compliance with the actual condition of the students of the department of accounting at STIE Binaniaga who have perceived that being an accountant or an auditor in the Government Office is the beginning of a misery. The students' perception about a professional accountant (Pr) does not have any significant correlation with the students concerned who want to work as a public accountant in the government office (M1) The students' perception about the accountancy scandals does not have any significant correlation with the dependent variable M1 (The students' interest to work at a Government Office). The students do not think that the accountancy scandals are correlated with their interest to work as a public accountant at the Government Office, but they think that their perception about some cases at the Government Office is the reason for them to work as public accountant at the Government Office. B4 variable which is the perception about KAP (Public Accountant Office) Big 4 does not correlate significantly with M2 which is the interest of the students who want to pursue a career in the Public Accountant Office. Acccording to the result above, it is conluded that the interest of the students who want to work in a Public Accountat Office is due to the perception about the professional accountant instead of the perception about the Big 4 of public accountant office itself. The students' perception about the professional accountant is having a negative and significant correlation with M2 which is the interest of the students who want to pursue a career in a Public Accountant Office, it has indicated that the more the perception of the students about professional accountant happened, the less the interest of the students who want to work at the Public Accountant Office, and vise versa. The students' perception about the accountancy scandals does not have any significant correlation with M2 which is the interest of the students who want to pursue a career in the Public Accountant Office. The perception of the students about the accountancy scandals is quite big, however, they do not think that such the scandals will be the reason of their future career. Perception of the students about Professional Accountant (B4) does not have any correlation with the interest of the students who want to pursue a career in auditing (M3). The students have assumed that their perception about professional accountant is more relevant instead of the perception about Public Accountant at the Government Office as the reason why they want to pursue a career in auditing. Their perception about professional accountant is having a significant and negative correlation with M3 which is the interest of the students to pursue a career in auditing where $t$ value of $\operatorname{Pr}$ variable is -2.304 . It is indicating that the more the perception of the students about professional accountant is, the less the interest of the students who want to pursue a career in auditing, and vise versa. Perception about the accountancy scandals is not correlating significantly with the interest of the students who want to pursue a career in auditing. Students of STIE Binanbangsa have perceived that such the scandals are only a perception instead of the reason of pursuing a career in auditing.

Perception of the students about accountancy scandals does not have any significant correlation with the interest of the students to work as public accountant at the Government Office, to work at the Public Accountant Office, and to pursue a career in auditing. However, the students' perceptions about audit scandals and professional

Rizki Ahmad Fauzi. Correlation between the student's perception about professional public accountant and the intention to pursue the career in auditing at the students of department of accounting STIE Binaniaga 
accountant have significantly correlated with the interest of the students. The interest of the students of Department of accounting at STIE Binaniaga who want to pursue a career in auditing and at the Public Accountant Office has been defined by their perception about Professional Accountant. To be more specific, the interest of the students concerned to work as public accountant at the Government Office is determined by their perception about the scandals happened. It has been questioned before that the result of the research might have produced a negative impact for the interest of the students to continue a career in the professional public accountant. Based on the result of this research, the perception of the students about the accountancy scandals does not have any significant correlation with the students' interest to pursue a career in auditing at the Public Accountant Office. It is possible that negative and wrong or unreliable students' perception about either professional public accountant or Public Accountant Office could decrease their interest to pursue a career in auditing. Based on the result above, the students or the lecturers of department of accounting should have given a proper perception about professional public accountant in detail and in overall, nevertheless, the lecturers who work at Public Accountant Office could share their perception and experience to the accountancy students accordingly.

\section{Conclusion and Suggestion}

The students' percepton about professional public accountant has negatively and significantly correlated with the interest of the students to be an accountant at the Government Office, however, their perception about professional accountant (Pr) and accountancy scandals (Sk) does not have any significant correlation with the related interest. Nevertheless, the students' perception about professional accountant (Pr) has correlated negatively and significantly with the interest of the students who want to pursue a career in a Public Accountant Office (M2). Their perception about professional accountant $(\mathrm{Pr})$ has correlated negatively and significantly with the students' interest to pursue a career in auditing (M3).

\section{References}

Arens, A.A., Elder, R.J., Beasley, M.S. (2012). Auditing and Assurance Services: an Integrated Approach (14th ed.). Essex, England: Pearson Education, Inc.

Association of Certified Fraud Examiners (ACFE). (2010). Report to The National Asia Pasific (Online). http://www.ethicsline.com/pdf/2010-ACFEReport-to-NationsAsia-Pacific.pdf, Accessed on April 7, 2013.

Association of Certified Fraud Examiners (ACFE). (2002). Report to Nation (Online). http://marketplace.cfenet.com/Download.asp, Accessed on November 26, 2012.

BAPEPAM. (2003). Siaran Pers Hasil Pemeriksaan Laporan Keuangan dan Perdagangan Saham PT Bank Lippo Tbk (Online). http://www.bapepam.go.id/old/old/news/Maret2003/PR_LIPPO.pdf, accessed on April 7, 2013.

BAPEPAM. (2002). Laporan Tahunan BAPEPAM tahun 2002 (Online). http://www.bapepam.go.id/pasar_modal/publikasi_pm/annual_report_pm/20 02/AR_2002.pdf, Accessed on April 7, 2013.

Black's Law Dictionary. (2012). What is FRAUD (Online). http://thelawdictionary.org/fraud/, Accessed on November 25, 2013.

Rizki Ahmad Fauzi. Correlation between the student's perception about professional public accountant and the intention to pursue the career in auditing at the students of 
Campbell, S., Tatyana, B., Barbara, P.R. (2003). Using Expectancy Theory to Assess Group-Level Differences in Student Motivation: A Replication in the Russian Far East. Issues in Accounting Education. May: 125-136.

Comunale, C.L., Sexton, T.R., Gara, S.C. (2006). Professional ethical crises: A case study of accounting majors. Managerial Auditing Journal: 636- 656.

Jones, K., Mcintyre, D. (2002). Will Enron deter students from majoring in accounting?. The CPA Journal, December: 13-5.

Gani, L., Leo, L. (2009). Ujian Sertifikasi Akuntan Publik: Determinan, Pola Kelulusan, dan Evaluasi Ujian. Jurnal Akuntansi dan Keuangan Indonesia, 6 (2).

Ghozali, I. (2009). Ekonometrika: Teori, Konsep dan Aplikasi dengan SPSS 17. Semarang: Badan Penerbit Universitas Diponegoro.

Grazella, M. (2012). RI 2nd most fraud-prone country: Report (Online). http://www.thejakartapost.com/news/2012/10/17/ri-2nd-most-fraud-pronecountryreport.html , Accessed on November 26, 2012.

Ikatan Akuntan Indonesia. 2008. Kode Etik Ikatan Akuntan Indonesia. (Online). http://www.iaiglobal.or.id/tentang_iai.php?id=18, Accessed on 7 April 16, 2013.

Ikatan Akuntan Indonesia. (2012). Akuntan Indonesia Gamang Menghadapi AFTA 2015 (Online). http://www.iaiglobal.or.id/v02/berita/detail.php?catid=\&id=511, Accessed on April 17, 2013.

Institut Akuntan Publik Indonesia. (2012). Sertifikasi Akuntan Publik (Online) http://www.cpaindonesia.or.id/informasi.html , Accessed on 7 April 24, 2013.

Kotler, P., Wrenn, B., Shawchuck, N. (2010). Biulding Strong Congregations. USA: Autumn House.

Malthus, S.M., Fowler, C. (2008). Perceptions of Accounting as a Career: A Qualitative New Zealand Study. Afaanz/iaaer Conference 6-8 July 2008.

Nugroho, B.A. (2005). Strategi Jitu Memilih Metode Statistik Penulisan dengan SPSS. Yogyakarta: C.V Andi Offset.

Qomariyah. (2005). Skandal World Com (Online). http://finance.detik.com/read/2005/03/16/102449/318371/6/sosok/arsip.html, Accessed on April 16, 2013.

Republik Indonesia. 2011. Undang-Undang Republik Indonesia Nomor 5 Tahun 2011 Tentang Akuntan Publik (Online) http://datahukum.pnri.go.id/index.php?option=com_phocadownload\&view=catego ry\&download=1098:uuno5th2011\&id=23:tahun-2011\&ltemid=27 , Accessed on April 24, 2013.

Robbins, S.P. (2008). Perilaku Organisasi. Buku 1, Edisi 12. Diterjemahkan oleh Diana Angelica. Jakarta: Salemba Empat.

Scholl, R.W. (2002). Motivational Process-Expectancy Theory. October.

Setiyani, R. (2005). Faktor-Faktor Yang Membedakan Mahasiswa Akuntansi Dalam Memilih Profesi Sebagai Akuntan Publik Dan Non Akuntan Publik: Studi Empiris Pada Mahasiswa Akuntansi Perguruan Tinggi Negri di Pulau Jawa (Online)

Rizki Ahmad Fauzi. Correlation between the student's perception about professional public accountant and the intention to pursue the career in auditing at the students of department of accounting STIE Binaniaga 
The Accounting Journal of BINANIAGA Vol. 04, No. 01, June 2019

p-ISSN: $2527-4309$, e-ISSN: $2580-1481$

$5^{\text {th }}$ Accreditation Rating: January 14, 2019 - January 13, 2024

http://eprints.undip.ac.id/10225/1/2005MAK3680.pdf , Accessed on April 15, 2013.

Sihwahjoeni., Gudono, M. (2000). Persepsi Akuntan terhadap Kode Etik Akuntan. Jurnal Riset Akuntansi Indonesia. 3 (2): 168-184.

Soemarso, S,R. (2004). Akuntansi Suatu Pengantar. Edisi 5. Jakarta: Salemba Empat.

Sulaiman, W. (2004). Analisis Regresi Linier Berganda dengan SPSS. Yogyakarta: Graha IImu.

Sumarna, A. (2002). Sarjana Akuntansi dan Potensi yang Perlu Digali. Media Akuntansi 30, Edisi Des. 2002-Jan 2003:17-20.

Sunaryo. (2004). Psikologi untuk Keperawatan. Jakarta: Penerbit Buku Kedokteran.

Tan, L.M., Laswad, L. (2006). Students' beliefs, attitudes and intentions to major in accounting. Accounting Education: An International Journal. 15(2). 167-187.

Vona, Leonard .W. 2006. Fraud Definition (Online). http://www.fraudauditing.net/FraudDefinitions.pdf , Accessed on November 26, 2013.

Velasques. (2006). Enron's Fall (Online). http://mujilan.files.wordpress.com/2012/04/kasus-enron.pdf , accessed on 7 April 2013.

Widarno, B. (2007). Profil dan Kompetensi Sarjana Akuntansi. Jurnal Ekonomi dan Kewirausahaan, 7 (2): 150-159.

Yendrawati, R. (2007). Persepsi Mahasiswa dan Mahasiswi Akuntansi Mengenai FaktorFaktor yang Mempengaruhi Pemilihan Karir sebagai Akuntan. Fenomena, 5 (2).

Rizki Ahmad Fauzi. Correlation between the student's perception about professional public accountant and the intention to pursue the career in auditing at the students of department of accounting STIE Binaniaga 